\title{
Financial Structure Effects on Jordanian Banks Tobin's Q
}

\author{
Sanaa. N. Maswadeh* \\ Jadara University, Irbid, Jordan.
}

\begin{abstract}
This study aims to investigate the effect of the ownership structure includes (institutional, government, foreign, managerial, and concentration ownership) which is considered as one of the institutional governance tools, on the financial performance of Jordanian commercial banks as measured in Tobin's Q. The study population consisted of all Jordanian commercial banks listed at the Amman Stock Exchange. Hypotheses of the study were tested using the multiple regression models. Among the most prominent findings of the study are a significant positive effect of institutional and concentration ownership on Tobin's Q, while managerial ownership affected negatively on Tobin's Q. Moreover, there was no effect of government and foreign ownership on Jordanian Banks Tobin's Q.
\end{abstract}

Keywords: Concentration ownership, foreign ownership, Government ownership, Institutional ownership, Managerial ownership.

JEL Classification: Q21, G32, M41

\section{INTRODUCTION}

For the goals and interests of owners and managers to be compatible they face several issues. These include the differing objectives of owners and managers because of different attitudes towards risk and diversification, as well as having differences regarding company conditions, its future, and the ability to interpret it. This leads to issues of information asymmetry which causes difficulties in owners monitoring managers' actions; this leads to owners bearing costs for setting mechanisms encouraging managers to make decisions in accordance with their interests .

This misalignment of interests and agency issues does not appear only between managers and shareholders, but also extends to other parties, for instance between shareholders, minority shareholders and shareholders, and creditors and the rest of the other stakeholders. This results in a requirement for a number of mechanisms and rules to form frameworks to monitor and supervise management actions and behaviors; this is to reduce issues of conflicts of interest in order to guarantee the protection of the interests of the rest of the parties. This motivates managers to invest in shareholders' interests and increase company value, which has led to the emergence of the concept of corporate governance (Mehrani et al., 2016). The rules and mechanisms of governance emphasize the achievement of a balance between company manager interests and those of other stakeholders and shareholders, in addition to which the company is managed transparently, and rationally to achieve and protect the objectives of various parties' interests. The financial structure is regarded as an institutional governance tool by which supervision and control role are exercised by shareholders where

*Address correspondence to this author at Jadara University, Irbid, Jordan, Mob-00962796745498, E-mail: mmsana59@gmail.com the majority of them have greater control of administrative behaviors than minor shareholders .

When the share of shareholders increases, the control role increases; the expectation is that this will be reflected in improvement of company performance. Shyu (2013) stated that financial structure is the various patterns of equity of shareholders' financial structure of the company's shares. The effect of financial structures on company financial performance has increased the attention of a number of researchers since the separation between capital and management, which is a basic element of stock companies where the right of owners is to control and make decisions which are mandated to a specialized group of managers who have competence in company management. Consequently, this highlights the importance of compatibility between owner and manager interests in the continued survival of the company. Regarding companies where their financial structure is distributed amongst many owners where they all have a limited amount of shares, the managers can then make decisions which allow them to reach their interests as a result of the shareholders' lack of incentives in closely monitoring companies' activities, as well as the weak participatory nature of shareholders in taking decisions or implementing policies. In regard to companies characterized by financial structure which is concentrated with the major owners, financial institutions or those which are subjected to the control of foreign ownership or governmental ownership, they are controlled and followed-up by owners since there have the authorities and motivations to monitor management behaviors and lower agency problems. This includes ensuring the interests of others are respected and that managers are motivated to act within company interests, shareholder interests, and towards an increase in company value.

Therefore, interest asymmetry between management and company bodies such as shareholders, creditors, the govern- 
ment and others, has caused a number of issues which have resulted from the endeavors of each of those parties attempting to maximize its benefit, even when that is at the expense of benefit of other parties. This has led to an increase in the importance of studying financial structure effects and its various components (institutional, government, foreign, managerial and concentration ownership) on financial achievement which is measured by Tobin's Q indicator, where this indicator adopts the tangible and intangible factors which affect a company's value. It also considers a measure used for evaluating companies where a comparison is made between share market and book value, especially since markets are considered an important performance indicator for performance evaluation .

The criticality of the research highlights how important the study subject is, since financial structure is one governance mechanism which aims to control management decisions and practices which result in maximizing its self-benefit. This limits any agency issues and protects investors from exploitation by the administration, in addition to directing investor attention on the financial markets towards explaining the differences in financial structures and their effect on company performance; this helps them to make rational investment decisions. Additionally, assisting creditors in their awareness of financial structure effects on company performance when making financing decisions and assisting regulatory and supervisory bodies, such as the central bank and the Securities Commission, aids the adoption of required control procedures and instructions in regard to company financial structure for performance improvement. Therefore, the expectation is that this will reflect on financial market effectiveness, national economic development, and increases rates of society welfare and economic development at both the local and international level .

The study's contribution is demonstrated through identifying the effects of the financial structure as a governance mechanism to achieve control role effectiveness upon the company's management and its effect on their decisions and behaviors. Therefore, trying to achieve a financial structure that achieves the idle balance based on share distribution between the company's management and other parties with the company's asymmetry interests aiming at increasing the benefit of all parties and increases its value. Consequently, this study expects to enhance the accounting literature by adding new results to what has been studied from Arab and foreign studies on the effect of the financial structure on Jordanian commercial bank performance, especially since most previous studies have focused on different sectors, including the industrial and service sectors. Additionally, this study attempts to discover the effect for 2013-2019, which is the most recent time span which can offer us evidence about the effects of the Jordanian bank financial structure performance, as measured in the Tobin's Q indicator in that recent period.

\section{LITERATURE REVIEW}

The legacy of institutional governance goes back to Berle \& Means, who first addressed the issue of separating ownership from management in 1932. Institutional governance is defined as a set of processes and procedures that a company must have to be managed in the best possible way to achieve benefits to the stakeholders (John and Senbet, 1998). The governance structure establishes the responsibilities and the rights between the different groups in relation to companies' activities, for instance the board of directors, stakeholders, and shareholders. In addition, it determines the rules and procedures for making decisions related to company affairs in addition to structures whereby companies' goals are determines, and how they will achieve and control them. Lei (2009) defined institutional governance as the mechanisms that owners use to control management actions to maximize profits. Elghouti (2015) indicated that institutional governance mechanisms for solving issues arising from company ownership and management separation (agency problem) as well as problems associated with the dispersal of ownership in the organization. Fleming et al., (2005) stated that the decisions of the financial structure reflect attempts to improve company performance when such decisions aim to lower agency issues among the various stakeholders in the company and which can lead to lower costs which in turn positively reflect upon company performance.

A study by Masmah (2018) aimed to identify the effect of financial structures on company financial performance for those on the Palestine Stock Exchange, which showed that there exist positive influences of ownership concentration on financial performance. This also revealed a significant negative effect of institutional ownership of financial activity on Palestine companies. Acero et al., (2017) studies the effects of financial structure as measured by concentration ownership on the financial activity of the European Football Association's five major leagues from 2007-2012 .

The study concluded that there is a significant negative effect of concentration ownership on financial activity. Al-Anati (2017) aimed toward the identification of the effects of financial structure and company characteristics on earning quality in Jordanian insurance companies on the Amman Stock Exchange. The results showed significant negative effects of institutional ownership upon quality of earnings while significant positive effects were found of government ownership on quality of earnings .

Ahmed and Abdel Hadi (2017) showed the effect of financial structures on financial activity in 8 Arab countries depending on the financial statements of industrial companies for all countries during the year (2014). One crucial aspect of the research is significant positive effects of concentration ownership on companies' financial performance while family ownership negatively affected company financial company performance .

The study of Altemimi and AbuSamra (2016) showed the effects of institutional ownership on share market value of the Jordanian industrial and service companies on the Amman Stock Exchange. This research discovered a significant positive effect of institutional ownership upon share market value for Jordanian industrial and service companies. A study by Harb (2015) aimed to discover the effects of financial structure on Jordanian bank performance on the Amman Stock Exchange from 2010-2014.

Financial performance was gauged using return on assets, return on equity, and Tobin's $\mathrm{Q}$ indicator. The study discov- 
ered that there is a significant effect of concentration ownership on Tobin's Q indicator and there was not any significant effect of concentration ownership on return on equity or return on assets. Rahman, et al., (2015) study researched the effect of financial structures on Malaysian bank activity from 2000-2011. The bank's activity was measured by return on equity and return on assets. The results demonstrate that there were significant effects of government and managerial ownership on the performance of Malaysian banks, as well as significant effects of institutional ownership on return on equity, but there was no significant effect of family and foreign ownership on the financial activity of Malaysian banks. Al-Badri (2016) looked at the effects of institutional ownership on Egyptian bank performance, and reached the conclusion that there were significant positive effects of institutional ownership on Egyptian bank performance. Abu Saud, et.al. (2014) tested the effects of financial structure on Jordanian industrial company activity. The results showed that if the company manager is descended from the same family and owns the company then this will have negative effects on Jordanian industrial company activity. Additionally, it found that managerial, concentration and government ownership positively affected industrial company performance. Kiruri (2013) tested the effects of financial structure on Kenyan bank profitability .

Crucially, the results indicate a positive effect of foreign ownership on the profitability of banks. Chen and Yu (2012) research looked at the effect of financial structure on company activity in Scandinavia. This indicated a positive effect of foreign ownership and concentration ownership on Kenyan bank profitability. Mandaci and Gumus (2010) examined both managerial ownership and concentration ownership of non-financial companies' value and profitability on the Istanbul Stock Exchange. The research concluded that there are positive effects of concentration ownership on company value and its profit, with negative effects of managerial ownership on firm value. Al Shlool (2012) aimed to know the effect of managerial ownership upon financial decisions in Jordanian industry. It indicated a negative effect of managerial ownership upon financial decisions in Jordanian industry .

Fazlzadeh, et al., (2011) attempted to identify the role of the financial structure on Iranian company performance from 2001-2006. It discovered no significant effect of concentration ownership upon Iranian company performance and that there was not a positive significant effect of institutional ownership on Iranian company activity. Abu-Serdaneh, et al., (2010) investigated ownership patterns in Jordanian industrial companies on the Amman Stock Exchange. Research shows that Jordanian company ownership is more concentrated in a few categories of investors and the approximately relative constant percentage of foreign and institutional ownership from 2002-2006.It showed a significant negative effect of concentration ownership and significant positive effects of institutional ownership, while there was not any significant effects of foreign and managerial ownership, on the activity of Jordanian industry. The Mazumder (2017) studied the effect of corporate control, measured by ownership structure, on top-executives' compensation in non-financial firms publicly traded on the first section and second section of the Tokyo Stock Exchange (TSE), Japan.
Such finding is limits managerial self-dealing and curves the increase in top-executives' pay. On the other hand, the results also show that management-controlled firms are more likely to extract more compensation from the business than other firms. This study confirms that corporate control has significant impact on cash compensation paid to Japanese management.

The objective of ( Vu, et.al, 2020) paper is to clarify the factors influencing system risks of listed companies in Vietnam, with a focus on clarifying the relationship and quantifying the impacts of ownership structure on systemic risk of listed companies. The results of the paper showed that state ownership and foreign ownership by investors were positively related to systemic risk, while ownership by domestic investors had a negative relation on systemic risk of listed companies in Vietnam. In addition, as a control variable, both company size and profitability had an effect on the systemic risk of listed companies in the research sample. Tran, et.al (2020) studied the relationship between ownership structure factors and earnings management behavior of Vietnamese commercial banks. The results of the study showed that the foreign ownership ratio is an opposite effect, while the concentration ownership has a positive effect on earnings management behavior of Vietnamese commercial banks. Masum etc.al (2020) aimed to investigate the impact of ownership structure on corporate voluntary disclosure in the listed companies of Bangladesh. The results indicate a significant negative relationship between public ownership and corporate voluntary disclosure, while no significant relationships between institutional ownership and voluntary disclosure, while director ownership, and foreign ownership, have been found.

Habtoori (2020) studied the potential effect of concentration ownership on the relationship between board composition and bank performance. The empirical results reveal a significant negative moderating effect of concentration ownership on the association between board composition and bank performance. The results indicate that board composition in terms of independent board members, executive board members, and non-executive board members with higher concentration ownership have low positive influence on bank performance. The study emphasized for regulatory authorities, companies, and market participants in Saudi Arabia and countries with high concentrated ownership, to understand how concentration ownership would affect corporate governance and firm performance and to identify appropriate actions to protect board composition from the influence of concentration ownership

After referring to past research, this study aims to complement past research; particularly where most previous research differed in the nature of the effects of financial structure on financial performance, which was studied in various performance measures and in various industrial sectors. The study next intends to test the effects of financial structure on Jordanian commercial bank financial activity, which is measured depending on the Tobin's Q indicator and the following main hypothesis which is to be tested:

"There is no statistically significant effect of the financial structure represented in (institutional, government, foreign, 
managerial and concentration ownership) on Tobin's Q indicator in Jordanian commercial banks."

\section{MATERIALS AND METHODOLOGY}

The study methodology uses an analytical method of financial data announced in the Jordanian Securities Commission and Jordanian Center Bank for the commercial banks from 2013-2019.

The study populations are all Jordanian commercial banks which traded its shares on the Amman Stock Exchange, a total of 16 banks. The study sample uses the entire Jordanian commercial bank population so that the financial reports issued by them can be used to calculate Tobin's Q, in addition to data published by the Jordanian Center Bank to obtain financial structures data of the Jordanian Commercial Banks.

The research measures their variable and is displayed in table 1:

Table 1. Summary of Study Variables.

\begin{tabular}{|c|c|c|}
\hline \multirow{1}{*}{$\begin{array}{c}\text { Dependent } \\
\text { variable }\end{array}$} & Study variables & Way of measurement \\
\cline { 2 - 3 } & Tobin's Q & $\begin{array}{c}\text { The ratio of the market value of the } \\
\text { company's shares to its book value. }\end{array}$ \\
\hline & $\begin{array}{c}\text { institutional own- } \\
\text { ership }\end{array}$ & $\begin{array}{c}\text { The number of shares owned by } \\
\text { institutions investors to the total } \\
\text { number of issued and traded shares. }\end{array}$ \\
\cline { 2 - 4 } Independent & $\begin{array}{c}\text { government own- } \\
\text { ership }\end{array}$ & $\begin{array}{c}\text { The number of shares owned by the } \\
\text { public (government) institutions to } \\
\text { the total number of issued and traded } \\
\text { shares. }\end{array}$ \\
\cline { 2 - 4 } & $\begin{array}{c}\text { foreign ownership } \\
\text { vable }\end{array}$ & $\begin{array}{c}\text { The number of shares owned by non- } \\
\text { total number of issued and traded } \\
\text { shares. }\end{array}$ \\
\cline { 2 - 4 } & $\begin{array}{c}\text { managerial owner- } \\
\text { ship }\end{array}$ & $\begin{array}{c}\text { The number of shares owned by the } \\
\text { board of directors to the total number } \\
\text { of issued and traded shares. }\end{array}$ \\
\cline { 2 - 4 } & $\begin{array}{c}\text { The percentage of owners whose } \\
\text { ownership percentage exceeds (5\%) } \\
\text { of the total number of issued and } \\
\text { traded shares. }\end{array}$ \\
\hline
\end{tabular}

\section{STATISTICAL METHODS}

A number of tests are employed where each test suits why it is used, including descriptive statistics and arithmetic mean, minimum and maximum value and standard deviation to show the descriptive characteristics of the study variables. Besides, Variance Inflationary Factor is relied upon to check the absence of interference and autocorrelations among the study's independent variables. The multiple regressions model tests the ability of independent variables to interpret the dependent variable and test the study hypotheses.

\section{RESULTS}

Descriptive analysis of the financial structure represented by (institutional, government, foreign, managerial and concen- tration ownership) is conducted with the independent variables as well as Tobin's Q indicator as a dependent variable, as illustrated in table (2):

Table 2. Descriptive Characteristics of Studies Variables.

\begin{tabular}{|c|c|c|c|c|c|}
\hline & $\mathbf{N}$ & Mean & $\begin{array}{c}\text { Std. Devia- } \\
\text { tion }\end{array}$ & Max & Min \\
\hline Tobin's Q & 80 & 1.067 & 0.45 & 2.48 & 0.54 \\
\hline Institutional & 80 & 0.67 & 0.23 & 1 & 0.30 \\
\hline Government & 80 & 0.011 & 0.023 & 0.076 & 0.00 \\
\hline Foreign & 80 & 0.058 & 0.06 & 0.301 & 0.00 \\
\hline Managerial & 80 & 0.53 & 0.28 & 1 & 0.099 \\
\hline Concentrate & 80 & 0.65 & 0.20 & 1 & 0.082 \\
\hline \multicolumn{6}{|c|}{ Source: Result output from SPPS statistical analysis } \\
\hline
\end{tabular}

As illustrated in the table (2), the arithmetic means of Tobin's Q indicator greater than (1) means that the market values of commercial bank shares are higher than their book value. Additionally, this is based on ratios of financial structure and the rise of arithmetic mean of institutional ownership followed by concentration ownership, then managerial ownership with an arithmetic means of (0.67), (0.65) and (0.53) respectively. While government ownership and foreign ownership of the shares of Jordanian commercial banks occupies the last place with arithmetic means of (0.011) and (0.058) respectively .

\section{Test of Study Hypotheses}

The SPPS statistics-22 program is used to examine study data and test its hypotheses using the multiple regression model related to the effects of the financial structure of Jordanian commercial banks on Tobin's Q indicator, as illustrated in Table (3):

Table 3. Result of the Multiple Regressions Model.

\begin{tabular}{|c|c|c|c|c|c|}
\hline \multicolumn{6}{|c|}{$\begin{array}{rl}\text { Tobin's } \mathrm{Q}_{\mathrm{i}, \mathrm{t}}=1.177+0.375 & * \mathrm{In}_{\mathrm{i}, \mathrm{t}}+10.99 * \mathrm{GO}_{\mathrm{i}, \mathrm{t}}+-2.046 * \mathrm{FO}_{\mathrm{i}, \mathrm{t}}+-0.22 \mathrm{MA}_{\mathrm{i}, \mathrm{t}} \\
& +0.326 * \mathrm{CO}_{\mathrm{i}, \mathrm{t}}+\varepsilon_{\mathrm{it}}\end{array}$} \\
\hline & B & $\mathrm{T}$ & Sig. & VIF & Tolerance \\
\hline constant & 1.177 & 6.35 & 0.00 & & \\
\hline $\mathrm{In}_{\mathrm{i}, \mathrm{t}}$ Institutional & 0.36 & 2.39 & 0.02 & 4.866 & 0.206 \\
\hline $\mathrm{GO}_{\mathrm{i}, \mathrm{t}}$ Governmen & 0.33 & 0.15 & 0.46 & 4.202 & 0.238 \\
\hline $\mathrm{FO}_{\mathrm{i}}$, Foreign & -0.21 & -0.38 & 0.10 & 1.592 & 0.628 \\
\hline $\mathrm{MA}_{\mathrm{i}, \mathrm{t}}$ Managerial & -0.22 & -2.01 & 0.004 & 4.111 & 0.243 \\
\hline $\mathrm{CO}_{\mathrm{i}, \mathrm{t}}$ Concentrate & 0.49 & 2.56 & 0.00 & 1.343 & 0.745 \\
\hline$R=0.554$ & $\left(R^{2}\right)=0.406$ & \multicolumn{4}{|c|}{ Adjusted $\left(R^{2}\right)=0.36$} \\
\hline \multicolumn{2}{|c|}{$F=6.541$} & \multicolumn{4}{|c|}{ Sig F. $=0.000$} \\
\hline
\end{tabular}

Source: Result output from SPPS statistical analysis. 
Referring to the table (3) regarding the variance inflationary factor, it is clear that independent variables (VIF) values are fewer than (5) and every tolerance value is greater than $(0.20)$. Therefore, every independent variable passed the test, meaning that there are no issues of linear interference or autocorrelations between the independent variables. Table (3), the explanatory coefficient value (Adjusted R2) $=0.36$ confirms that the combined independent variables (government, foreign, institutional, concentration, and managerial ownership) explain $36 \%$ of changes in Tobin's Q indicator in Jordanian commercial banks. In regard to the significance of the (F) values of the models, the values of significance are less than $(5 \%)$, meaning that the explanatory coefficient (Adjusted R2) in the regression model has statistically significance at a significance level of $(\alpha \leq 0.05)$. This proves a statistically significant effect of financial structure (concentration, institutional, foreign, government and managerial ownership) on Jordanian commercial bank financial performance, as measured in the Tobin's Q indicator.

Table 3 shows the results of the multiple regression analyses and indicates that the value of regression coefficient of institutional ownership is (0.36) and the significance level is (0.02), meaning that there are significant positive effects of institutional ownership in the Tobin's Q indicator at a significant level $(\alpha \leq 0.05)$. The results are consistent with several studies including Al-Badri (2016), Mehrani, et al., (2016), Zhang (2005), Lin and Fu (2017), Kullab and Yan (2015), and Rajgopal, et al., (2002), Nelson and George (2013) and Abu-serdaneh et al., (2010). Additionally, this result differs from research by Al-Anati (2017), Lemma, et al., (2018), AlNajar (2015) and Falahnejad and Taheri (2014) who arrived at the conclusion that institutional ownership negatively affects company performance .

Table (3) shows that the regression coefficient of government ownership on the Tobin's Q indicator is (0.33), and the level of significance is (0.46) meaning that no statistically significant effects of government ownership on the Tobin's Q indicator were found at a significant level $(\alpha \leq 0.05)$. These results indicate consistence with research by Durnev and Fauver (2008), who found that institutional governance does not often occur in companies with high government ownership. This result is different from that of Al-Anati (2017), Rahman et al., (2015) and Abu Saud, et al., (2014), showing that government ownership affects company financial performance .

Table No (3) shows that the values of foreign ownership regression coefficient is $(-0.21)$ and the level of significance is $(0.10)$, showing no significant effects of foreign ownership upon Tobin's Q indicator at a significant level $(\alpha \leq 0.05)$. This finding concurs with that of Rahman et al., (2015) and Abu-serdaneh, et al., (2010), who concluded that there is no effect of foreign ownership upon company activity. The results differ from studies by Khamis et al. (2015), Harb (2015), Kiruri (2013), Jusoh (2015) who found a significant effect of foreign ownership upon company financial performance.

Additionally, table (3) indicates that the regression coefficient of the effect of managerial ownership on Tobin's Q indicator is (-0.22) and the level of significance is (0.004), which shows a significant negative effect of managerial ownership on Tobin's Q indicator at a significant level $(\alpha \leq$ $0.05)$ ). The results differ from those of Abu Saud et al., (2014) and Rahman et al., (2015), who discovered a positive effect of managerial ownership upon firm financial performance, also concurring with Abu-serdaneh, et al., (2010), who concluded that there is not an effect of managerial ownership upon the activity of Jordanian industrial companies.

Table (3) also shows the value of the regression coefficient of the concentration ownership is (0.49) and a significance level of (0.00) meaning that there is not a significant positive effect of concentration ownership on the Tobin's Q indicator at the significance level of $(\alpha \leq 0.05)$. This result agreed with Ozili, and Uadiale (2017), Ahmed and Abdel Hadi (2017), Yasser and Almamun (2017), Mandaci and Gumus (2010) and Ruan, et al., (2011), and differs from Fazlzadeh, et al., (2011), showing no significant effect of concentration ownership on the performance of Iranian companies.

\section{DISCUSSION}

The study returned several results and recommendations, the most important of which are:

Positive effects of institutional ownership structure can be found on the Tobin's Q indicator, in reference to the investing institutions for a large percentage of company shares, putting them in a more powerful position in comparison to minor shareholders and provides them with the rights to more efficiently participate in supervising and controlling management behaviors and decisions. This results in decreased agency costs and activates the various mechanisms of governance such as increasing the amount of institutional investors' members on the directors' board and the audit committee that leads to increases in their independence and also increases the effectiveness of company performance.

In addition, institutional investors are able to gain internal and external information about the company invested in it which in turn has positive effects on improving the financial performance of companies.

There is no significant effect of government ownership upon the Tobin's Q indicator, particularly when the percentage of government ownership in Jordanian commercial banks is low. The descriptive statistics in table (2) show that the percentage of government ownership of Jordanian commercial banks is $(0.01)$ and is the lowest financial structure percentage of Jordanian commercial banks .

There is no significant effect of foreign ownership upon the Tobin's Q indicator, meaning that there is no foreign ownership role in activating governance mechanisms in Jordanian commercial banks. This indicates that these investments, or part of them, are aimed at speculating and obtaining capital gain in the short term. This is especially true for the middle east region's conditions over the previous five years, which have caused a decline in share prices contributing to the encouragement of foreign investors to purchase them when the market improves, and which is not intended for medium-and long-term investment .

Managerial ownership indicates that management board members own company shares, which shows significant negative effects on the Tobin's Q indicator as the high per- 
centage of managerial ownership leads to a guarantee of the stability of managers' positions which pushes them to act in their own interests instead of seeking to increase company value. Also, as the management may exaggerate bonuses and additional benefits, even at the expense of external shareholder interests, the effect of conflicts of interest between them and other owners leading to negative effects on company financial performance.

Concentration ownership has positively affected Tobin's Q indicator, particularly when concentration ownership intends to improve company governance in light of increasing the ownership percentage during the period and the continuation of the preservation of its shares. This provides greater motivation to deepen its understanding of the business nature of companies and increases its ability to monitor the company business and follow up on companies implementing their strategies and goals.

\section{CONCLUSION}

Based on the results of the study, the researcher concludes that the financial market securities commission shall develop policies and legislation encouraging managers to disclose financial structure ratios of Jordanian companies to encourage the investment of major investors in these companies which positively affects financial performance. Besides, the audit committee shall activate its role in Jordanian companies by monitoring ownership percentages of companies, especially the managerial ownership which is aimed at activating its positive role and enhancing company financial performance .

Additionally, it is necessary to improve procedures and policies which attract and encourage non-Jordanian investors to invest in Jordanian companies, which will exert positive effects upon company activity in the long term. This is particularly true if real investments are to achieve returns, rather than speculation. Finally, researchers should be encouraged to expand their research on the effects of financial structure in other areas, in addition to implementing this research which relies on other financial performance indicators to enhance the study results .

\section{CONFLICT OF INTEREST STATEMENT}

The authors declare that they have no conflict of interest.

\section{REFERENCES}

Abu Al-Saud, Rajiha \& Abu Qeblan (2014),. The Impact of Ownership Structure on Corporate Performance, Arab Journal of Accounting, 17 (1) 37- 66.

https://journal.uob.edu.bh/bitstream/handle/123456789/1811/AJA1 70102.pdf?sequence $=1$ \&isAllowed $=y$

Abu-Serdaneh, Zuriekat, \& Al-Sheikh (2010), Ownership Structure and Corporate Performance in the Jordanian Manufacturing Companies, Jordan Journal of Business Administration 6 (3), 426-439. https://journals.ju.edu.jo/JJBA/article/view/1979

Acero, Isabel, Serrano, Raúl, \& Dimitropoulos, Panagiotis, (2017), Ownership Structure and Financial Performance in European Football, Corporate Governance: The International Journal of Business in Society, 17 (3), 511-523. doi.org/10.1108/CG-07-2016-0146

Ahmad, Niveen \& Abdel Hadi, Ola. (2017). Impact of Ownership Structure on Firm Performance in the Mena Region: An Empirical Study,
Journal of Accounting and Finance, 6(3), 105-115. doi.org/10.5430/afr.v6n3p105

Al Shlool, Dena, (2012), The Impact of Managerial Ownership on Financial Decisions: The Case of Jordanian Industrial Companies. Un Published Master Theses, Yarmouk University, Irbid, Jordan. http://thesis.mandumah.com/Record/220009

Anati, Radwan. (2017), The Impact of Ownership Structure and Corporate Characteristics on Earnings Quality: An Empirical Study on the Jordanian Insurance Sector, Zarqa Research and Humanities Studies Journal, 17 (1), 30-30.

http://zujournal.zu.edu.jo/index.php/16-3-2017/757-2017-06-0411-37-18

Al-Badri, Mohammed, (2016). The Impact of Bank Shares Ownership on the Performance of Companies Listed on the Egyptian Stock Exchange. Un -Published Master Theses, Ain-Shams University, Egypt, Cairo.

http://srv4.eulc.edu.eg/eulc_v5/Libraries/Thesis/BrowseThesisPage s.aspx?fn=PublicDrawThesis\&BibID $=12065508$

Al-Najjar, Dana. (2015). The Effect of Institutional Ownership on Firm Performance: Evidence from Jordanian Listed Firms, International Journal of Economics and Finance, 7(12), 79-105.

Altemimi, A. \& Abu Samra, H (2016).The Effect of Financial Leverage, Dividend Payout Ratio and Firm Features on Market Value of Share An applied Study on Companies Listed on Amman Stock Exchange, The Journal of Al Kut Journal of Economics Administrative Sciences,34 (3), 392-416. https://www.iasj.net/iasj?func $=$ article \&aId $=117888$

Chen, C-J .\& Yu, C-MJ. (2012), Managerial Ownership, Diversification, and Firm Performance: Evidence from an Emerging Market, International Business Review, 21,(1) 518-534. doi.org/10.1016/j.ibusrev.2011.06.002

Durnev \& Fauver, (2008), Stealing from Thieves: Firm Governance and Performance when States are Predatory, CEI Working Paper Series. http://cei.ier.hit-u.ac.jp/index.html

Elghouti, Amal, (2015), Effect of Ownership Structure on Firms Stock Returns and Financial Performance Evidence from the Egyptian Stock Market, Unpublished Master Theses, Plymouth University, United Kingdom. http://hdl.handle.net/10026.1/3358.

Falahnejad, F., \& Taheri, M. (2014). The Investigation of Relationship between Earnings Quality and Institutional Ownership, Applied Mathematics in Engineering, Management and Technology, Journal of Management and Technology, 17(2), 147-156. https://arabci.org/Articles?id=151969

Fazlzadeh, A., Hendi, A., \& Mahboubi, K. (2011). The Examination of the Effect of Ownership Structure on Firm Performance in Listed Firms of Tehran Stock Exchange Based on the Type of the Industry, International Journal of Business and Management, 6(3), 249266.

https://www.researchgate.net/publication/50315309_The_Examinat ion_of_the_Effect_of_Ownership_Structure_on_Firm_Performanc e_in_Listed_Firms_of_Tehran_Stock_Exchange_Based_on_the_T ype_of_the_Industry

Fleming, Grant, Heaney, Richard \& Mc Cosker, Rochelle, (2005), Agency Costs and Ownership Structure in Australia, Pacific-Basin Finance Journal, 13(1), 29-52. https://ideas.repec.org/a/eee/pacfin/v13y2005i1p29-52.html

Habtoori, Omer, (2020), The Moderating Role of Ownership Concentration on the Relationship between Board Composition and Saudi Bank Performance, Journal of Asian Finance, Economics and Business, 7(10), 675-685. doi:10.13106/jafeb.2020.vol7.no10.675

Harb, Heba, (2015), The Impact of Ownership Structure on Performance: An Empirical Study on Jordanian Banks, Master's Thesis, Yarmouk University. http://pqdtopen.proquest.com/\#viewpdf?dispub=3494547

John, Kose, \& Senbet, Lemma., (1998), Corporate Governance and Board Electiveness, Journal of Banking \& Finance, 22,(1), 371-403. doi.org/10.1016/S0378-4266 (98)00005-3Get

Joush, Abdullah. (2015). Foreign Performance: Evidence from Malaysia Ownership and Firm,. Asian Journal of Accounting and Governance; 6(3), 49-54. doi.org/10.17576/ajag-2015-6-7326

Khamis, Reem; Hamdan, Allam Mohammed, \& Elali, Wajeeh, (2015), The Relationship between Ownership Structure Dimensions and Corporate Performance: Evidence from Bahrain, Australasian Accounting, Business, and Finance Journal, 9 (4), 38-56. doi:10.14453/aabfj.v9i4.4 . 
Kiruri, R. M. (2013). The Effects of Ownership Structure on Bank Profitability in Kenya. European Journal of Management Sciences and Economics, 1(2), 116-127.

https://www.semanticscholar.org/paper/THE-EFFECTS-OFOWNERSHIP-STRUCTURE-ON-BANK-IN-KENYAKiruri/a8726fe89c76e9be7a0116f813ff08476d8f7c56

Kullab, Yarob, \& Yan, Chen. (2015). The Impact of Institutional Ownership on Income Accounting Strategy: Evidence from Bahrain, Journal of Academy of Accounting and Financial Studies, 22(1), 1-17. https://www.abacademies.org/articles/the-impact-of-institutionalownership-on-income-accounting-strategy-evidence-from-bahrain6995.html

Lei, D. Y. (2009), Privatization Ownership Structure and Performance of China Listed Companies in Split Share Structure Reform, Unpublished Thesis, University of Maryland, Maryland. https://doc.mbalib.com/view/8af87142630f7922c55adb573503bc77 .html

Lemma, Tesfaye T, Nagash, Minga, MliloMthokozisi, \& Lulseged, Ayalew. (2018). Institutional Ownership, Product Market Competition, and Earnings Management: Some Evidence from International Data, Journal of Business Research, 9(38), 151-163. doi.org/10.1016/j.jbusres.2018.04.035

Lin, Rebbeca, \& Fu, Maggie. (2017). Does Institutional Ownership Influence Firm Performance?: Evidence from China, International Review of Economics \& Finance 49(16), 17-57. https://www.researchgate.net/publication/312665049_Does_institut ional_ownership_influence_firm_performance_Evidence_from_Ch ina

Mandaci, P. \& Gumus, G. (2010), Ownership Concentration, Managerial Ownership, and Firm Performance: Evidence from Turkey, South East European Journal of Economics and Business, 5(1), 57-66. https://www.degruyter.com/view/j/jeb.2010.5.issue-0054.xml?format=INT

Masmah, Shoaib, (2018), The impact of the ownership structure on financial performance, Un -Published Master Theses, Islamic University, Gaza, Palestine.

Masum, Mofijul, Latiff, Ahmed, \& Oman, Mohammad, (2020), Ownership Structure and Corporate Voluntary Disclosures in Transition Economy, Journal of Asian Finance, Economics and Business, 7 (10) 601-611. doi:10.13106/jafeb.2020.vol7.no10.601

Mehrani, Sasan, Moradi, Mohammad, \& Eskandar, Huda. (2016). Institutional Ownership Type and Earnings Quality: Evidence from Iran. Emerging Markets Finance and Trade, 53(1), 54-73. doi.org/10.1080/1540496X.2016.1145114

Mazumder, Mohammed, (2017), Top-Executives' Compensation: The Role of Corporate Ownership Structure in Japan, Journal of Asian Finance, Economics and Business, 4(3), 35-43.

Mehrani, Sasan, Moradi, Mohammad, \&amp; Eskandar, Huda. (2016). Institu-tional Ownership Type and Earnings Quality: Evidence from Iran. Emerging Markets Finance and Trade, 53(1), 54-73.
doi.org/10.1080/1540496X.2016.1145114

Nelson M. W.; \& George K. R. (2013) Corporate Governance, Firm Attributes and Earnings Management in an Emerging Economy. Journal of Applied Management and Accounting Research, 11(1), 43-64 https://www.researchgate.net/publication/303854568_Corporate_g overn-

ance_firm_characteristics_and_earnings_management_in_an_emer ging_economy

Ozili, Kitakogelu, \& Uadile, Olayinka. (2017). Ownership Concentration and Bank Profitability, Journal of Future Business, 3(2), 159-147. https://www.researchgate.net/publication/317593080_Ownership_ Concentration_and_Bank_Profitability

Rahman, Abdul, Azureen, Nora, \& Farida, Anis, (2015). Ownership Structure and Bank Performance. Journal of Economics, Business, and Management, 3(5), 443-453. http://www.joebm.com/papers/232M00007.pdf

Rajgopal, S., Venkatachalam, M., \& Jiambalvo, J.(2002). Is Institutional Ownership Associated with Earnings Management and the Extent to which Stock Prices Reflect Future Earnings? Working Paper. https://onlinelibrary.wiley.com/doi/abs/10.1506/EQUA-NVJ9E712-UKBJ

Ruan, W., Tian, G., \& Ma, S. (2011). Managerial Ownership, Capital Structure, and Firm Value: Evidence from China's Firms, Journal of Australasian Accounting Business \& Finance, 5(3), 1-22. https://www.researchgate.net/publication/228897108_Managerial_ Ownership_and_Firm_Value_Evidence_from_China's_Civilianrun_Firms

Shyu, Jonchi, (2013), Ownership Structure, Capital Structure, and Performance of Group Affiliation: Evidence from Taiwanese Group-Affiliated Firms, Managerial Finance, 39 (4), 404- 420. doi.org/10.1108/03074351311306210

Tran, Thinh, Ly, Anh, \& Nguyen, Dung, (2020), Relationship between Ownership Structures and Earnings Management Behavior in Vietnamese Commercial Banks, Journal of Asian Finance, Economics and Business, 7, (9) 401-407. doi:10.13106/jafeb.2020.vol7.no9.40

Yasser, Qaiser, \& Almamun, Abdullah. (2017),. The Impact of Ownership Concentration on Firm Performance: Evidence from an Emerging Market, Journal of International Management Institute, 3(1), 34-53. https://www.researchgate.net/publication/316077806_The_Impact_ of_Ownership_Concentration_on_Firm_Performance_Evidence_fr om_an_Emerging_Market

Vu, Van Thi, Phan, Nghia, \& Dang, Hung,(2020), Journal of Asian Finance, Economics and Business, 7 (2), 107-117. doi:10.13106/jafeb.2020.vol7.no2.107

Zhang P., L. (2005), Is Value Riskier than Growth? The Journal of Financial Economics, 78(1), 187-202. http://theinvestmentcapm.com/PetkovaZhang05JFE.pdf 